\title{
Assessment of the effect of water-table depth on riparian vegetation along the middle and lower reaches of the Manasi River, Northwest China
}

\author{
Zhan Wang $^{1,2} \cdot$ Wenke Wang $^{1,2} \cdot$ Zaiyong Zhang $^{1,2} \cdot$ Xinyue Hou $^{1,2} \cdot$ Lei Duan $^{1,2} \cdot$ Dongjie Yao $^{3}$
}

Received: 30 November 2019 / Accepted: 10 December 2020 / Published online: 12 February 2021

(C) The Author(s) 2021

\begin{abstract}
The Manasi riparian zone in northwestern China has become a survival habitat for numerous native plant species and requires urgent protection owning to rapid expansion of farmland. The critical factor affecting the growth of desert riparian vegetation in arid regions is recognized to be groundwater, but in this region the threshold of water-table depth for riparian species has been rarely studied. To determine the association between species and their major growth factors and to ascertain the water-table depth threshold, this study employed field investigation, a logarithm distribution model and canonical correspondence analysis. According to the findings, (1) the water-table depth largely regulates the species distribution; (2) from the results of the logarithm distribution model, the water-table depth appropriate for herbs is $1-1.5 \mathrm{~m}$ and for shrubs it is $2-4 \mathrm{~m}$, and a water-table depth of less than $6 \mathrm{~m}$ could satisfy the growth requirement of major species; (3) species diversity peaks at the water-table depths of 2-3, $3-5$, and $2-4 \mathrm{~m}$ for herbs, shrubs and all species, respectively; (4) the frequency of appearance of Phragmites communis (grass herb) and Tamarix chinensis (deciduous shrub) was not as sensitive to depth to water table. To reconstruct a riparian zone, Phragmites communis and Tamarix chinensis could be planted in areas with water-table depth of less than $3 \mathrm{~m}$ and 2-5 m, respectively. These results may contribute to suitable policy regarding vegetation restoration.
\end{abstract}

Keywords Riparian zone $\cdot$ Ecology $\cdot$ Logarithm distribution model $\cdot$ Groundwater threshold $\cdot$ China

\section{Introduction}

The riparian corridor considered in this study is situated at the interface between the upland terrestrial ecosystems and stream ecosystems (Rundel and Sturmer 1998b; Gregory Wallace 1997). In relation to the entire landscape, the corridor is small

This article is part of the topical collection "Groundwater recharge and discharge in arid and semi-arid areas of China"

Wenke Wang

wenkew@chd.edu.cn

1 Key Laboratory of Subsurface Hydrology and Ecological Effects in Arid Region, Ministry of Education, Chang'an University, Xi'an, People's Republic of China

2 Present address: School of Water and Environment, Chang'an University, Yanta Road 126, 710054 Xi'an, Shaanxi, People's Republic of China

3 College of Geology and Mining Engineering, Xinjiang University, Xinjiang, China at the global scale (Rundel and Sturmer 1998b; Ström et al. 2012), whereas its level of species diversity is high (Gumiero et al. 2015; Rundel and Sturmer 1998b). The riparian species are critical to the preservation of ecosystem function as they provide reproduction sites for wildlife (Ellis 1995; Carothers et al. 1974; Merritt and Bateman 2012; Le Maitre et al. 1999), preventing desert invasion (Lammerts et al. 2001) and producing organic matter (Wallace et al. 1997; Hao et al. 2010). Hence, in order to protect the riparian species while maintaining a high level of species diversity, further insights into the relationship between species and environmental factors is necessary. Accordingly, the present study is urgently required for the Manasi riparian corridor (northwestern China) especially, to ensure the survival of habitat for native vegetation in face of long-term farm expansion.

In arid regions, stream water, precipitation, and groundwater are widely regarded as the three major natural water sources for the growth of the riparian species. The Manasi riparian zone is situated in the inland basin at the north piedmont of the Tianshan Mountains and is known for its extreme arid climate. The zone has scarce rainfall, which may hardly affect vegetation growth 
directly (Yang et al. 2017). Moreover, because of long-term surface-water allocation, $96.27 \%$ of the surface water is transferred for irrigation purposes. Often there is insufficient surface water to provide water by periodic overbank flooding for riparian species (Yang 2017). Accordingly, in the groundwater discharge zone, riparian vegetation is primarily dependent on groundwater to maintain its growth and function. Across the flood plain, groundwater can be exploited by deep-rooted plants and is a vital indirect water source for shallower-rooted vegetation through the regulation of soil-moisture content (Smith et al. 1998; Hao et al. 2009).

The riparian corridor ecosystem is complex, and many other factors besides the availability of water interact to affect the species distribution and diversity (Ward 2001; Xiong et al. 2003). A considerable number of studies have explained how species diversity, evolution and coverage are affected by environmental factors such as water-table depth, chemical composition of the groundwater, soil-water content and soilsalt content (Lymbery et al. 2003; Lv et al. 2013; Chen et al. 2014; Yang et al. 2013; Klijn and Witte 1999; Srivastava and Jefferies 1995; Stromberg 2007; Jansson et al. 2007). To investigate the effects of each factor on riparian vegetation, and to ascertain the primary factor affecting species the most, a number of approaches have been used, including principal component analysis (PCA), binary discriminant analysis (BDA), detrended canonical correspondence analysis (DCCA), canonical correspondence analysis (CCA), regression tree analysis, etc. Numerous studies in arid regions have reported that species distribution, diversity and vegetation cover are regulated by water-table depth (Hao et al. 2010; Zhu et al. 2013; Zhu et al. 2011). A drop of groundwater level can reduce the water availability, while a rise in groundwater level is capable of reducing oxygen levels in the vadose zone (Hao et al. 2010). The variation of water-table depth will induce species succession (Stromberg et al. 1996). Accordingly, in terms of species growth, a proper water-table depth must be maintained within a certain range. Many investigations have assessed the water-table depth in arid and semi-arid regions (Hao et al. 2010; Jin et al. 2016). Nevertheless, as there may be differences in climate, depositional environment and species composition, etc. among riparian zones, further investigations are required to delve into the appropriate water-table depth threshold, particularly in northwestern China.

The groundwater discharge from upland areas is capable of supporting a stable water resource for riparian species growth along the middle and lower reaches of the Manasi River. Nevertheless, the noticeable expansion of farmland and poorly managed water allocation have caused the area of wetland to become narrowed, and riparian vegetation has been degraded along the lower reach of the Manasi River due to lowering of the riparian water table (Wer et al. 2017). Thus, in order to protect and restore the riparian species, groundwater contribution to riparian vegetation should be urgently assessed, and its threshold should be determined. To date, very few investigations have been undertaken in this area. Accordingly, the present study aimed to (1) explore the contribution of water-table depth as a factor in species distribution; (2) assess the threshold of water-table depth; (3) provide basic data and analytical results for an assessment of the effects of human activities on riparian species and restoration of the riparian environment.

\section{Materials and methods}

\section{Study area}

The Manasi River is located at the southern Junggar Basin; it is $400 \mathrm{~km}$ long in total, arising from the North Tianshan Mountains and it flows though the Gurbantunggut Desert, entering Manasi Lake (Fig. 1). Geological and lithological structure have been changed along the river, and the river and groundwater systems have undergone significant transformation three times, which has regulated the variation of groundwater level and vegetation coverage on the regional scale (Wang et al. 2018). The area has a typical temperate continental climate, with an annual potential precipitation of 100-200 $\mathrm{mm}$, and an average annual evaporation of 1,500-2,100 $\mathrm{mm}$ (Yang et al. 2017). The riparian aquifer is a multilayer aquifer with fine-grained particles (Wang et al. 2018). Soil particle compositions within $0-1 \mathrm{~m}$ depth are listed in Table 1. Inflows of basin groundwater and river water have played an important role in maintaining the growth of riparian vegetation. The hygrophyte, xerophyte and mesophyte, including shrubs and herbs, have all grown in the Manasi riparian corridor, of which the dominant species are Tamarix chinensis, Apocynum venetum L., Carex spp., Phragmites communis, and Calamagrostis pseudophragmites (Table 2).

\section{Data collection}

Between August 2018 and September 2019, data were collected at 13 sites in the middle and lower reaches along the Manasi River riparian zone (Fig. 1). Each site consisted of a transect perpendicular to the major steam spanning the riparian zone (including floodplains and terraces) without adjacent upland farmland. Five plots $(10 \times 10 \mathrm{~m})$ were sampled at eight sites along the transect line at a distance of $10-30,50-70,100-120$, 200-250 and 500-650 m, and four plots $(10 \times 10 \mathrm{~m})$ were sampled at five sites at distances of 10-30, 50-70, 100-120, and 200-250 m away from the river. Shrub and trees were investigated in each plot $(10 \times 10 \mathrm{~m})$ and five herb plots of $1 \times 1 \mathrm{~m}$ were taken within the shrub and tree plot $(10 \times 10 \mathrm{~m})$. The geographical location for each plot, covering elevation, longitude and latitude, was recorded using a global positioning system (GPS). The vegetation investigation took place in August 


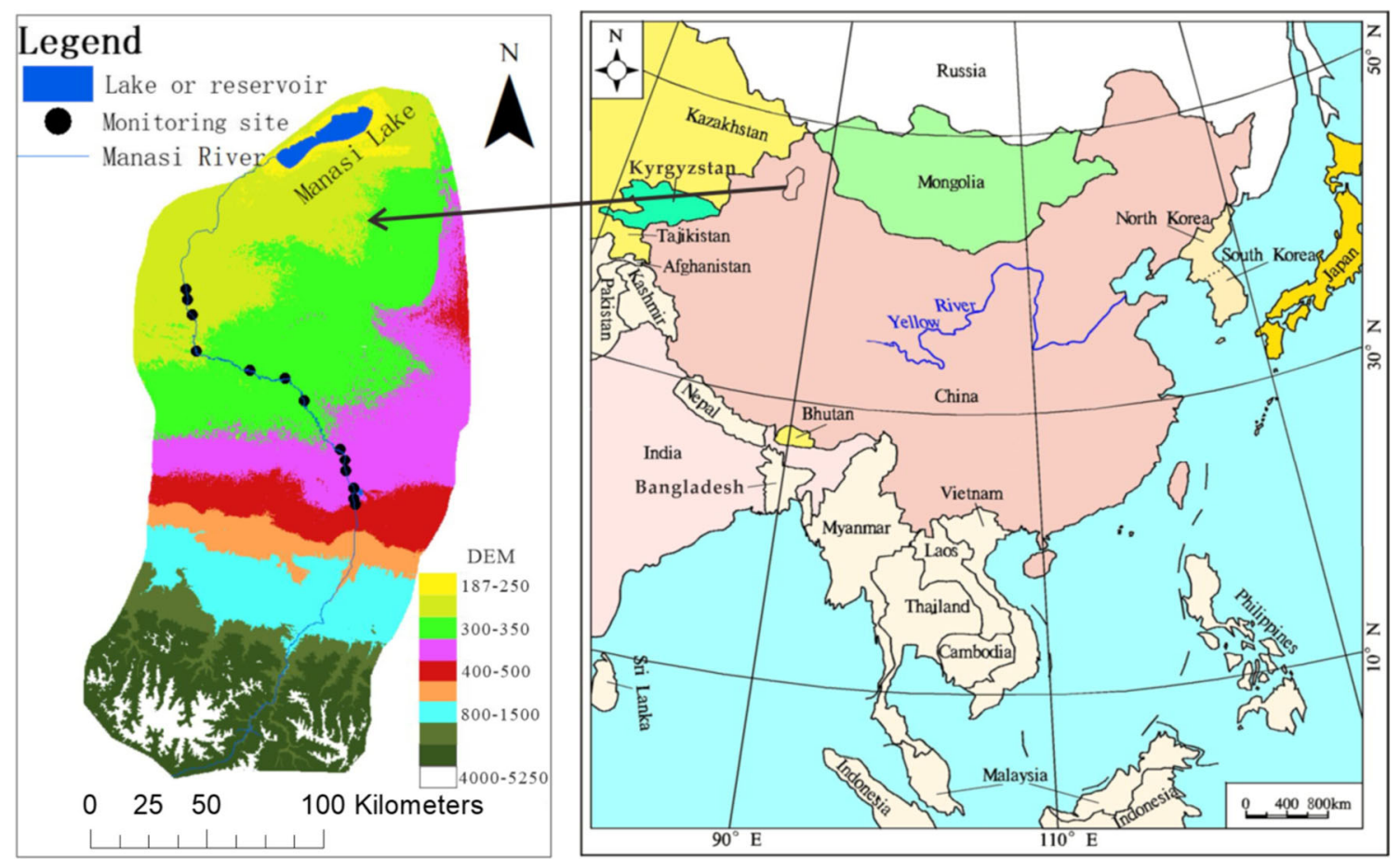

Fig. 1 Location of the Manasi River catchment and research site. Digital elevation (DEM) in $\mathrm{m}$ above mean sea level

2018 and August 2019. For each respective plot, the plant name, numbers of each plant, its height and the vegetation coverage were recorded. Estimation of the vegetation coverage of Phragmites communis and Tamarix ramosissima was in accordance with the principles put forward by Liu et al. (2012). In the plot, each side was divided into ten equal parts, and 20 ropes crossed vertically to form 100 nodes counting how many times the plant contacted the nodes, defining the contact times of 100 nodes as the vegetation coverage of this plant. In a $1 \times 1 \mathrm{~m}$ plot, each node was spaced $10 \mathrm{~cm}$ apart, and the contact times of Phragmites communis in 100 nodes were calculated as the coverage of Phragmites communis. In regard to the $10 \times 10 \mathrm{~m}$ plot, the spacing of each node was $10 \mathrm{~m}$, and the contact times of Tamarix ramosissima in 100 nodes were calculated as the coverage of Tamarix ramosissima. Since there were five herbaceous plants plots, the average value is denoted as the coverage of Phragmites communis. The value of species abundance was acquired using statistics, which was the number of each herb species in a $1 \times 1 \mathrm{~m}$ plot as well as each shrub species in a $10 \times$ $10 \mathrm{~m}$ plot. One well was drilled in the center of each plot $(10 \times$ $10 \mathrm{~m}$ ) with a depth of 7-12 $\mathrm{m}$ and groundwater was sampled in 60 wells. The total dissolved solids content was determined with a water quality detector in the field. The depth to groundwater level was measured once a month during August 2018 to September 2019 by a wooden rule or rope. The average watertable depth was used in the following analysis.

Soil sampling was performed alongside the vegetation investigation of each plot. A pooled sample was derived from three random cores at a depth of $0-1 \mathrm{~m}$ in each $10 \times 10 \mathrm{~m}$ plot using a $4.5 \mathrm{~cm}$ diameter soil auger. The soil samples were sealed in an aluminum specimen box and weighed in the field, then they were dried at $105^{\circ} \mathrm{C}$ for $24 \mathrm{~h}$. The percentage variation in mass could be used to calculate the soil-water content. The soil chemical constituents, such as $\mathrm{HCO}_{3}{ }^{-}, \mathrm{SO}_{4}{ }^{2}$ ${ }^{-}, \mathrm{Cl}^{-}, \mathrm{Ca}^{2+}, \mathrm{Mg}^{2+}, \mathrm{Na}^{+}$, and $\mathrm{K}^{+}$, as well as the corresponding $\mathrm{pH}$ values, were measured by the China Coal Xi-an Design Engineering Co., Ltd. Each anion was analyzed via titration following the standard method for geotechnical tests. Additionally, $\mathrm{pH}$ values were measured using a PHSJ-5 $\mathrm{pH}$ meter. The soil-moisture content, soil-salt content, and soil $\mathrm{pH}$ values were obtained from the $0-1 \mathrm{~m}$ layer.

\section{Data analysis}

The linear combination of two groups of variables, $X=\left[x_{1}, x_{2}, \ldots, x_{m}\right], Y=\left[y_{1}, y_{2}, \ldots, y_{m}\right]$, can be expressed as $X$ ' $=a_{x 1} x_{1}+a_{x 2} x_{2}+\ldots a_{x m} x_{m}=a^{\mathrm{T}} X, Y=b_{x 1} \mathrm{y}_{1}+b_{x 2} \mathrm{y}_{2}+\ldots$ $b_{x m} \mathrm{y}_{m}=b^{\mathrm{T}} Y$. $X^{\prime}$ and $Y^{\prime}$ are referred to as the canonical variables. The aim of CCA was to find the canonical variable with the largest correlation coefficient, and the correlation of the original variables can be expressed by the correlation of the canonical variable. Accordingly, sorting the quadrat, environmental factors and species may be done on the same graph (see Fig. 3), and the relationship between species distribution, community distribution and environmental factors may be intuitively observed. The quadrant where the arrow is pointed to represents the positive or negative correlation between environmental factors and the sorting axis. The length of the arrow represents the degree of 
Table 1 The results of soil particle analysis (unit: $\mathrm{mm}$ )

\begin{tabular}{|c|c|c|c|c|c|c|c|c|c|}
\hline \multirow[t]{2}{*}{ Site } & \multicolumn{2}{|l|}{ Rock } & \multicolumn{3}{|c|}{ Gravel } & \multicolumn{4}{|l|}{ Sand } \\
\hline & $>40$ & $20-40$ & $\begin{array}{l}10 \\
20\end{array}$ & $5-10$ & $2-5$ & $0.5-2$ & $0.25-0.5$ & $0.075-0.25$ & $<0.075$ \\
\hline 1 & 0 & $11.86 \pm 23.72$ & 0 & $59.08 \pm 17.84$ & $13.44 \pm 7.94$ & $6.75 \pm 4.46$ & $3.14 \pm 1.49$ & $5.16 \pm 5.67$ & 0 \\
\hline 2 & 0 & 0 & 0 & 0 & 0 & $6.30 \pm 5.87$ & $14.08 \pm 3.54$ & $25.76 \pm 5.18$ & $54.34 \pm 4.34$ \\
\hline 3 & 0 & 0 & 0 & 0 & 0 & $3.92 \pm 3.97$ & $10.72 \pm 5.91$ & $12.90 \pm 6.54$ & $72.46 \pm 11.67$ \\
\hline 4 & 0 & 0 & 0 & 0 & 0 & $18.68 \pm 18.2$ & $19.35 \pm 3.67$ & $37.20 \pm 11.65$ & $24.78 \pm 10.48$ \\
\hline 5 & 0 & 0 & 0 & 0 & 0 & 0 & 0 & $14.12 \pm 1.08$ & $84.8 \pm 1.53$ \\
\hline 6 & 0 & 0 & 0 & 0 & 0 & $0.7 \pm 0.80$ & $9.44 \pm 7.14$ & $11.66 \pm 1.33$ & $78.2 \pm 5.75$ \\
\hline 7 & 0 & 0 & 0 & 0 & 0 & 0 & $9.76 \pm 3.25$ & $8.02 \pm 2.86$ & $83.66 \pm 2.42$ \\
\hline 8 & 0 & 0 & 0 & 0 & 0 & 0 & 0 & $18.26 \pm 10.92$ & $81.74 \pm 10.92$ \\
\hline 9 & 0 & 0 & 0 & 0 & 0 & 0 & 0 & $12.7 \pm 0.2$ & $87.3 \pm 0.2$ \\
\hline 10 & 0 & 0 & 0 & 0 & 0 & 0 & 0 & $11.9 \pm 1.96$ & $88.1 \pm 1.96$ \\
\hline 11 & 0 & 0 & 0 & 0 & 0 & 0 & 0 & $24.6 \pm 2.17$ & $75.4 \pm 2.17$ \\
\hline 12 & 0 & 0 & 0 & 0 & 0 & 0 & 0 & $23.1 \pm 2.75$ & $76.9 \pm 2.75$ \\
\hline 13 & 0 & 0 & 0 & 0 & 0 & 0 & 0 & $73.42 \pm 2.91$ & $26.58 \pm 2.91$ \\
\hline
\end{tabular}

correlation between an environmental factor and the species distribution. The angle between the arrow and the sort axis represents the correlation between an environmental factor and the sorting axis. Canonical correspondence analyses (CCA) were conducted to reveal the relationships between vegetation composition and environmental factors. In this study, six environment factors were considered in the data matrix comprised of environmental factors, namely, water-table depth, total dissolved solids, groundwater $\mathrm{pH}$, soil-moisture content, soil-salt content, and soil pH. CANOCO 4.5 executed the CCA, which was designed by Ter Braak and Šmilauer (2002) for ordination analyses. In the ordination diagram (Fig. 3), the abbreviations represent the species name (see Table 2), and the arrows indicate the environmental variables (Ter Braak and Colin Prentice 1988). The Monte Carlo permutation test was done in conjunction with 499 random permutations so as to test the significance of each axis.

Gaussian regression has been extensively used to reflect the species and environmental relationship (Zhang 2004); however, the relationship between the vegetation and the environment is too sophisticated to guarantee full compliance with Gaussian regression. Certain related studies in Northwest China reported that the lognormal distribution is capable of describing the species occurrence frequency distribution as the variation in water-table depth (Hao et al. 2010). The probability density function is expressed as follows:

$$
\begin{aligned}
& f(x)=\frac{1}{x \sigma \sqrt{2 \pi}} \mathrm{e}^{\left(-\frac{[\ln (x)-\mu]^{2}}{2 \sigma^{2}}\right)} \\
& X_{\mathrm{pm}}=\mathrm{e}^{\mu-\sigma^{2}} \\
& E(X)=\mathrm{e}^{\mu+\frac{\sigma^{2}}{2}}
\end{aligned}
$$

$\sigma(X)=\left(\mathrm{e}^{\sigma^{2}}-1\right) \mathrm{e}^{2 \mu+\sigma^{2}}$

where $x$ denotes the water-table depth; $\mu$ is the mathematical expectation of $\ln x$; and $\sigma$ refers to the standard deviation of $\ln$ $x$; pm is a label and $X_{\mathrm{pm}}$ represents water-table depths corresponding to the peak value of the species appearance frequencies.

Three indices were adopted to calculate species diversity.

The Shannon-Wiener diversity index $(H)$ :

$H=-\sum_{i=1}^{S}\left(p_{i} \ln \left(p_{i}\right)\right)$

Patrick's index of richness:

$R=S$

Simpson's diversity index:

$D=1-\sum_{i=1}^{s} p_{i}^{2}$

where $p_{i}$ denotes the ratio of the plant number of species $i$ to the total plant number of all species in the plot, and $S$ represents the total number of species in the plot. The ShannonWiener diversity index and Simpson's diversity indices were then computed for the herbs and shrubs, which were based on the Eqs. (5) and (7) respectively. When calculating the Shannon-Wiener diversity index and Simpson's diversity index for the entire species, the indices of herbs and shrubs were weighed according to the vertical structure of the community, as proposed by Fan et al. (2006), Gao et al. (1997) and Zhu et al. (2013). The proposed equation was $H_{\text {total }}=W_{\text {herb }} H_{\text {herb }}+$ $W_{\text {shrub }} H_{\text {shrub }}+W_{\text {tree }} H_{\text {tree }}$ and, $D_{\text {total }}=W_{\text {herb }} D_{\text {herb }}+$ 
Table 2 List of species in the riparian along middle and downstream of Manasi River

\begin{tabular}{|c|c|}
\hline Plant type & Species \\
\hline Herbs & $\begin{array}{l}\text { Phragmites australis } \\
\text { Cirsium japonicum } \\
\text { Calamagrostis pseudophragmites } \\
\text { Sophora alopecuroides L. } \\
\text { Equisetum hyemale L. } \\
\text { Cynanchum sibiricum } \\
\text { Cynodon dactylon } \\
\text { Glycyrrhiza inflata } \\
\text { Salsola collina } \\
\text { Carex spp. } \\
\text { Scirpus yagara } \\
\text { Dactylis glomerata } \\
\text { Agropyron cristatum } \\
\text { Suaeda glauca } \\
\text { Typha orientalis } \\
\text { Artemisia selengensis } \\
\text { Dactylis glomerata } \\
\text { Agrostis alba L. } \\
\text { Seriphidium terrae-albae } \\
\text { Calamagrostis epigeios } \\
\text { Achnatherum splendens } \\
\text { Karelinia caspia } \\
\text { Aeluropus littoralis } \\
\text { Cyperus difformis L. } \\
\text { Artemisia lancea } \\
\text { Juncus effusus L. } \\
\text { Leymus secalinus } \\
\text { Arrhenatherum elatius } \\
\text { Erigeron canadensis } \\
\text { Salsola brachiata } \\
\text { Petrosimonia sibirica } \\
\text { Salsola tragus } \\
\text { Eleocharis yokoscensis } \\
\text { subsp. Viridis }\end{array}$ \\
\hline Shrubs & $\begin{array}{l}\text { Suaeda physophora } \\
\text { Tamarix chinensis } \\
\text { Alhagi sparsifolia } \\
\text { Halimodendron halodendron } \\
\text { Kochia prostrata } \\
\text { Apocynum venetum L. } \\
\text { Calligonum mongolicum } \\
\text { Poacynum hendersonii } \\
\text { Anabasis salsa } \\
\text { Caragana sinica } \\
\text { Apocynum venetum L. } \\
\text { Ephedra przewalskii }\end{array}$ \\
\hline Trees & $\begin{array}{l}\text { Elaeagnus angustifolia Linn. } \\
\text { Ulmus pumila L. } \\
\text { Populus alba }\end{array}$ \\
\hline
\end{tabular}

$W_{\text {shrub }} D_{\text {shrub }}+W_{\text {tree }} D_{\text {tree }}$; where $W_{i}=\left(\frac{c_{i}}{c}+\frac{h_{i}}{h}\right) / 2(i=1$ represents the herb layer; $i=2$ represents the shrub layer; and $i=3$ represents the tree layer); $c$ refers to the total vegetation cover in a $10 \times 10 \mathrm{~m}$ plot; $c_{i}$ stands for the vegetation cover for each layer; $h$ represents the average height for all the species; and $h_{i}$ signifies the average height for each layer. Statistics were used to calculate Patrick's index of richness as the number of all species that occurred within the $10 \times 10 \mathrm{~m}$ plot.

A generalized additive model (West 2012) takes the form of a regression model, where some or all independent variables are smooth spline functions, kernel functions or local regression smooth functions. This model can be expressed as $g[E(y)]=\beta_{0}+f_{1}\left(x_{1}\right)+f_{2}\left(x_{2}\right)+f_{3}\left(x_{3}\right)+\ldots f_{m}\left(x_{m}\right)$. Here, $g$ is a link function, $y$ is an independent variable and $f_{i}\left(x_{i}\right)$ is a smooth spline function, kernel function or local regression smooth function. The generalized additive model can unify the minimum residual and lowest possible degree of freedom. The generalized additive model was employed to explore the response curve of several vegetation diversity indices to water-table depth.

\section{Results}

\section{Response of soil-water content and soil-salt content to water-table depth}

In the study area, precipitation was low throughout the study duration. The soil moisture is dependent on the supply of groundwater. According to the results, the soil moisture content declined with an increase in water-table depth (Fig. 2a). At water-table depths of less than 1, 1-2, 2-3, 3-4 $\mathrm{m}$ and over $4 \mathrm{~m}$, the average soil-moisture content was $27 \% \pm 10 \% ; 12 \% \pm 5 \% ; 11 \% \pm 6 \% ; 6 \% \pm 2 \%$; and less than $3 \% \pm 1 \%$. Soil-salt content demonstrated a decreasing trend according to the increase in water-table depth (Fig. 2b). When the water-table depth surpassed $5.0 \mathrm{~m}$, the soil-salt content tended to be constant and may have been primarily affected by the parent material.

\section{The relationship between vegetation and environmental factors}

In regard to factors primarily affecting vegetation growth from existing studies, six environmental factors were selected to study their effects on plant species distribution. The position of each plant in Fig. 3 was the weighted average of all quadrats and species sequence values, representing the optimal environmental conditions for plant growth in the sequence diagram. The plants having an appearance frequency under $10 \%$ were not part of the analysis as canonical correspondence 

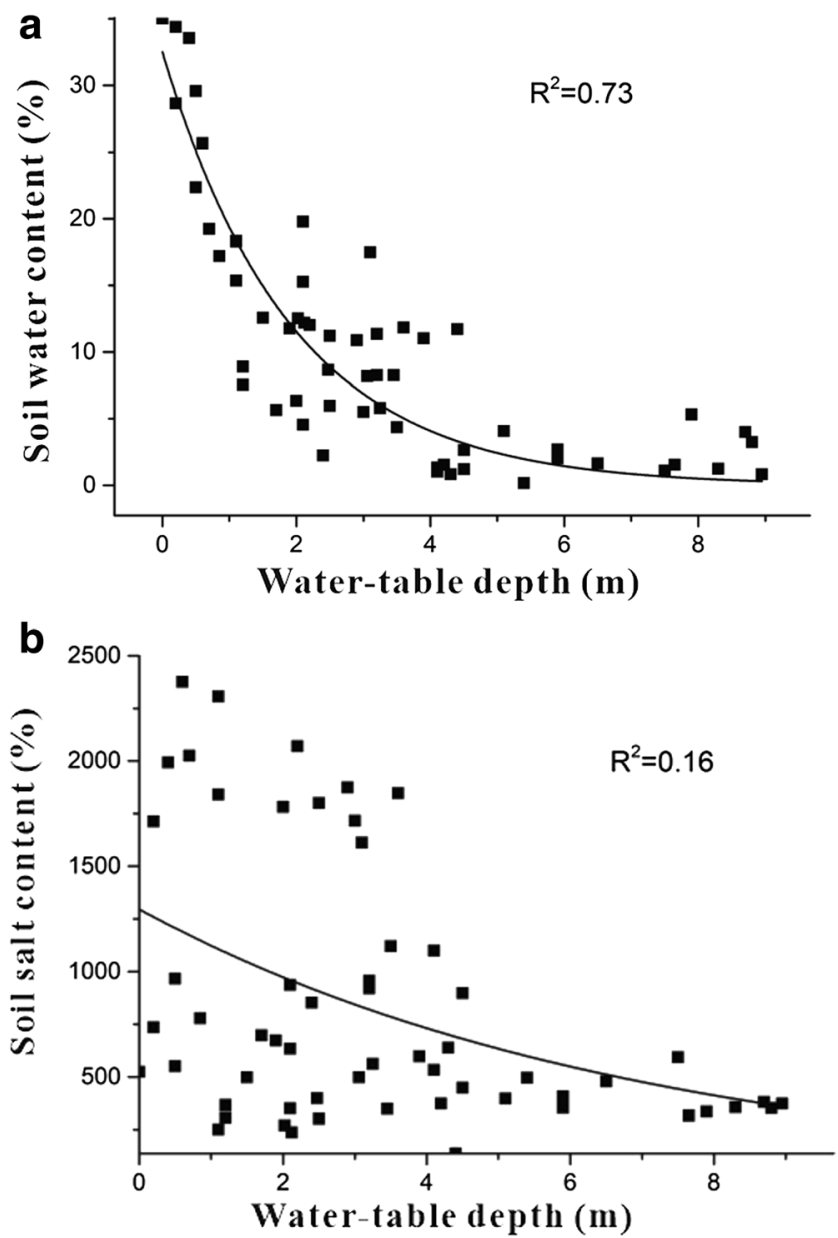

Fig. 2 Relationship between water-table depth and soil attributes: a soilwater content, $\mathbf{b}$ soil-salt content

analyses is sensitive to rare species. All of the initial four ordination axes were found to be highly significant

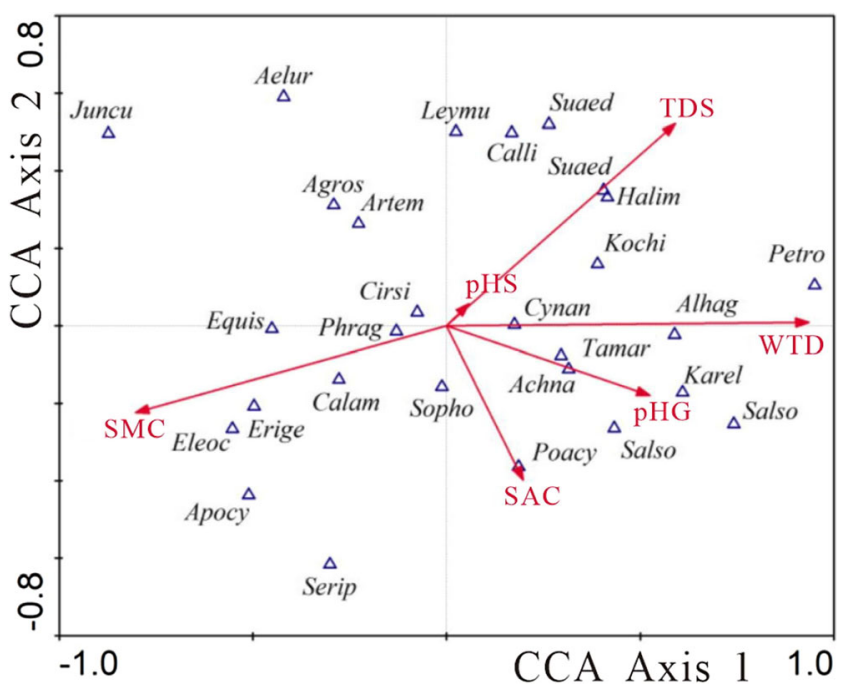

Fig. 3 Canonical correspondence analysis (CCA) ordination between species abundance and environmental factors in 60 plots (species name is represented by the first five letters and whole names are listed in Table 2) $(p<0.05)$, as indicated by a Monte Carlo permutation test. The water-table depth was significantly positively associated with the first axis $(p<0.01)$, while the soil-water content was significantly negatively related to the first axis $(p<0.01$; Tables 3 and 4). This revealed that as the water-table depth increased, soil-moisture content decreased along axis 1 from the left to the right. Therefore, the first axis represented the moisture gradient. Furthermore, the TDS and soil salt content were positively correlated with the second axis $(p<0.05)$; hence, the second axis represented the salt gradient. The previously mentioned results suggest that the availability of water was the critical factor in controlling the species spatial distribution.

\section{Gaussian regression analysis for vegetation and water-table depth}

According to the frequency of plant species occurrence, spatial distribution and dominant species, eight species were selected in order to plot regression curves based on the data regarding water-table depth and vegetation composition in each plot. Figure 4 and Table 5 illustrate the findings of the lognormal distribution analysis between vegetation occurrence frequency and water-table depth.

Table 5 states that the water-table depths corresponding to the peak value of the species appearance frequencies for Tamarix ramosissima, Alhagi sparsifolia Shap., Halimodendron halodendron, Kochia prostrata (L.) Schrad. were $2.88,3.98,3.75$, and $3.69 \mathrm{~m}$, respectively; while those of the species appearance frequencies for Phragmites communis, Cirsium japonicum, Calamagrostis pseudophragmites, Sophora alopecuroides L. were 1.21, 1.23, 0.95, and $1.48 \mathrm{~m}$, respectively. Accordingly, the appropriate watertable depth for herbs was found to be 1.0-1.5 m, whereas the depth for shrubs was nearly $2.5-4.0 \mathrm{~m}$. The average water-table depths $[E(X)]$ for Tamarix ramosissima, Alhagi sparsifolia Shap., H. halodendron and Kochia prostrata were 5.59, 5.06, 4.17, and $4.11 \mathrm{~m}$, respectively, while those for Phragmites communis, Cirsium japonicum, Calamagrostis pseudophragmites, and Sophora alopecuroides L. were 5.59, $3.59,2.37$, and $4.35 \mathrm{~m}$, respectively. Hence, water-table depth less than $6 \mathrm{~m}$ may satisfy the requirements for most herb and shrub growth. $\sigma(X)$ represents the tolerance of species to the fluctuation of the groundwater level. The value for herbs was obviously higher than that of shrubs, indicating that shrubs were more sensitive to variation in water-table depth. The $\sigma(X)$ value for Phragmites communis was observed to be the largest among the herb species, suggesting that Phragmites communis may serve to effectively resist drought. In the meantime, Tamarix ramosissima may be the shrub that most effectively resists drought. 
Table 3 Results of CCA ordination

\begin{tabular}{lccccc}
\hline \multirow{2}{*}{ Parameter } & \multirow{2}{*}{ Axis } & & & \\
\cline { 2 - 5 } & 1 & 2 & 3 & 4 \\
\hline Eigenvalue & 0.452 & 0.159 & 0.106 & 0.073 \\
Diversity-environment correlations & 0.907 & 0.743 & 0.553 & 0.632 \\
Cumulative percentage variance of species data & 10.6 & 14.3 & 16.8 & 18.5 \\
Cumulative percentage variance of species-environment relation & 52.5 & 71.0 & 83.3 & 91.7 \\
\hline
\end{tabular}

\section{The response curve of the species diversity indices to water-table depth}

In view of the findings from the generalized additive model, species richness for herbs was observed to be the highest at a water-table depth of 1.5-3.5 m, followed by depths $0-1.5 \mathrm{~m}$ and 3.5-5.5 m; while the lowest species richness was at the water-table depth greater than $5.5 \mathrm{~m}$. In regard to shrubs, the species richness was found to be the highest at the depth of $2.5-5.5 \mathrm{~m}$, followed by $5.5-8 \mathrm{~m}$, though it was the lowest at the water-table depth of less than $2 \mathrm{~m}$. In relation to both the herbs and shrubs parameters, the Shannon-Wiener diversity index and Simpson's diversity index demonstrated a similar trend along the water-table depth gradient. For herbs, the species diversity was seen to be greatest at a water- table depth of $1.5-3.5 \mathrm{~m}$, followed by $0-1.5$ and $3.5-5 \mathrm{~m}$, but lowest at a water-table depth larger than $5 \mathrm{~m}$. For shrubs, the species diversity was greatest at a water-table depth of 2.5-5 m, followed by 5-8 $\mathrm{m}$, but lowest at a water-table depth of less than $2.5 \mathrm{~m}$. In regard to all the species, both species diversity indices attained their largest values when the water-table depth range was $2-4 \mathrm{~m}$, followed by $1-2$ and $4-6 \mathrm{~m}$. At a watertable depth over $6 \mathrm{~m}$ or less than $1 \mathrm{~m}$, the species diversity was found to be low (Fig. 5).

\section{Changes in coverage of Phragmites communis and Tamarix ramosissima with water-table depth}

Phragmites communis and Tamarix ramosissima are two typical vegetation species in this region able to survive a wide range of water-table depths. The coverage of the two species in the different plots increased with an increase in water-table depth, but fell when water-table depth rose to a certain threshold. The average coverage of Phragmites communis was $40 \%$ at a water-table depth shallower than $2 \mathrm{~m}$; it was $50 \%$ at watertable depth of 2-3 m and 10\% at water-table depth larger than $4 \mathrm{~m}$. The average coverage of Tamarix ramosissima was less than $20 \%$ at water-table depth shallower than $2 \mathrm{~m}$ or deeper than $6 \mathrm{~m}$ but increased to $60 \%$ at water-table depth of $3-5 \mathrm{~m}$. (Fig. 6).

\section{Discussion}

In the present study, results showed that the water-table depth serves as a major factor in controlling plant species distribution and diversity, consistent with the conclusions of Zhu et al. (2011, 2013) and Hao et al. (2010). The maximum value for herb and all species diversity index was at a watertable depth of 2-4 m, followed by 1-2 and 4-6 m. However, in regard to the shrub diversity index, the maximum value appeared at water-table depth of 3-5 $\mathrm{m}$. At water-table depth less than $1 \mathrm{~m}$, due to strong evaporation and capillary action, soil salt accumulated, resulting in the largest level of the soil salt content. Such a large content of soil salt may trigger a low osmotic potential, reducing the availability of water to plants via root uptake, even for salt-tolerant species like Phragmites communis (Gorai et al. 2010). Subsequently, the vegetation diversity would be reduced. At the water-table depth over $4 \mathrm{~m}$, the soil-water content may not be affected by water-table
Table 4 Correlation coefficients of CCA ordination axes and six environmental factors

\begin{tabular}{lllll}
\hline Parameter & Axis & & \\
\cline { 2 - 5 } & 1 & 2 & 3 & 4 \\
\hline Water-table depth (WTD) & $0.8483^{* *}$ & 0.0059 & -0.1085 & -0.1528 \\
Total dissolved solids (TDS) of groundwater & $0.5359^{*}$ & 0.3879 & 0.0289 & 0.2929 \\
Soil water content (SMC) & $-0.7285^{*}$ & -0.1663 & -0.1631 & -0.0552 \\
Soil salt content (SAC) & 0.1789 & -0.2959 & -0.0493 & 0.5393 \\
Groundwater pH (pHG) & 0.4758 & -0.1338 & -0.0209 & -0.1980 \\
Soil pH (pHS) & 0.0516 & 0.0419 & 0.3591 & -0.0167 \\
\hline
\end{tabular}

*Represents significance level of $0.05, * *$ Represents significance level of 0.01 


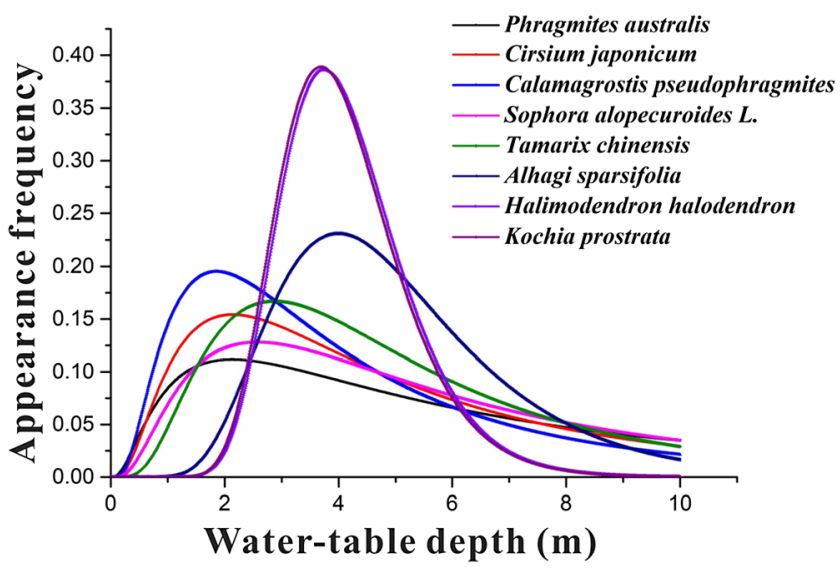

Fig. 4 Lognormal distribution curve between the appearance frequency of representative species and water-table depth

depth. At the water-table depth larger than $6 \mathrm{~m}$, herb vegetation could hardly exist; however, both the diversity and coverage of shrub vegetation decreased to a certain degree and slightly changed at water-table depth over $7.5 \mathrm{~m}$. The roots of the herb species were generally shallower than those of shrubs, and they primarily consumed soil water, while the roots of shrubs may reach a length of 3-10 m (Jackson et al. 1996). Accordingly, herb species diversity would rapidly decrease at water-table depth more than $4 \mathrm{~m}$, while the shrubs would respond to the variation in water-table until it decreased to $6 \mathrm{~m}$ below the land surface. As most herb species in the study area were perennial species, perennial herb species were suggested to be more sensitive to drought. Limitations in groundwater availability would reduce species richness, which was also observed by Lite et al. (2005) and Stromberg et al. (2010) and this was consistent with the findings of Liu et al. -Liu et al. 2006 in cited in the text but not found in the ref list. Please provide appropriate publishing details for this ref.->(2006) and Hao et al. (2010). However, Lv et al. (2013) yielded noticeably different results and found that shrub species were sensitive to water-table depth, while herb species were not easily affected by a decline in the water table in Hailiutu River catchment. Differences in climate or vegetation species and characteristics between the two study areas may have resulted in these discrepancies. The Hailiutu
River is located in a semi-arid region and has an annual precipitation of $350-500 \mathrm{~mm}$, and its soil water is able to recharge from rainfall; hence, herb species with shallow roots may not be easily affected by fluctuations in groundwater level. The Manasi River, on the other hand, is located in an arid region with an annual precipitation of less than $200 \mathrm{~mm}$, and the soil water is adjusted primarily via groundwater level. Various studies have put forward that, in arid regions, the amount and frequency of rainfall may hardly satisfy requirements in vegetation growth (Chen et al. 2004; Elmore et al. 2006). Given this, in the present study, the herbs were found to be readily affected by groundwater-level decline. The response curve of all species was quite similar to that of the herb species, suggesting that a decrease in herb species diversity could lead to a decrease of all-species diversity. Therefore, the appropriate water-table depth for maintaining species diversity is found to be $2-4 \mathrm{~m}$.

The Gaussian model reported that the optimum water-table depth was 1-4 m for several species found with a relative higher occurrence. At the water-table depth of more than $6 \mathrm{~m}$, various herbs and shrubs would be subject to water stress. A conclusion is that the critical water-table depth at which the herb and shrub species would be subject to water stress was determined to be $6 \mathrm{~m}$. Moreover, to optimally protect and restore the ecosystem in the Manasi River riparian belt, a water-table depth of 1-4 m should be maintained.

For stable water availability, the riparian zone where the river and groundwater have a direct hydraulic connection was found to be the ideal habitat for vegetation along the river (Wang et al. 2018), while large natural riparian species in this area were lost to farmland by excess agricultural reclamation (Yang et al. 2017; Yang 2017). Since the recovery of native vegetation is critical to the conservation of biodiversity and ecosystems (Lomelí et al. 2017), the authors support the concept put forward by Boonekauffman et al. (1997) that agricultural reclamation should be promptly stopped in order to give sufficient time for vegetation recovery. Simultaneously, modifying agriculture practices to raise or maintain groundwater levels is necessary, such as taking measures to increase irrigation efficiency. However, because the regeneration of native species in converted farmland may be very slow (Loster
Table 5 Parameters of the lognormal distribution fitting curves of eight main plant species unit: meters

\begin{tabular}{lllllll}
\hline Plant type & Species & $\mu$ & $\Sigma$ & $X_{\mathrm{pm}}$ & $E(X)$ & $\sigma(X)$ \\
\hline Herbs & Phragmites australis & 1.21 & 1.01 & 1.21 & 5.59 & 7.44 \\
& Cirsium japonicum & 0.92 & 0.85 & 1.23 & 3.59 & 3.67 \\
& Calamagrostis pseudophragmites & 0.56 & 0.78 & 0.95 & 2.37 & 2.17 \\
& Sophora alopecuroides L. & 1.11 & 0.84 & 1.48 & 4.35 & 4.40 \\
\multirow{4}{*}{ Shrubs } & Tamarix chinensis & 1.50 & 0.67 & 2.88 & 5.59 & 4.18 \\
& Alhagi sparsifolia & 1.54 & 0.40 & 3.98 & 5.06 & 2.11 \\
& Kochia prostrata & 1.38 & 0.27 & 3.69 & 4.11 & 1.12 \\
\hline
\end{tabular}



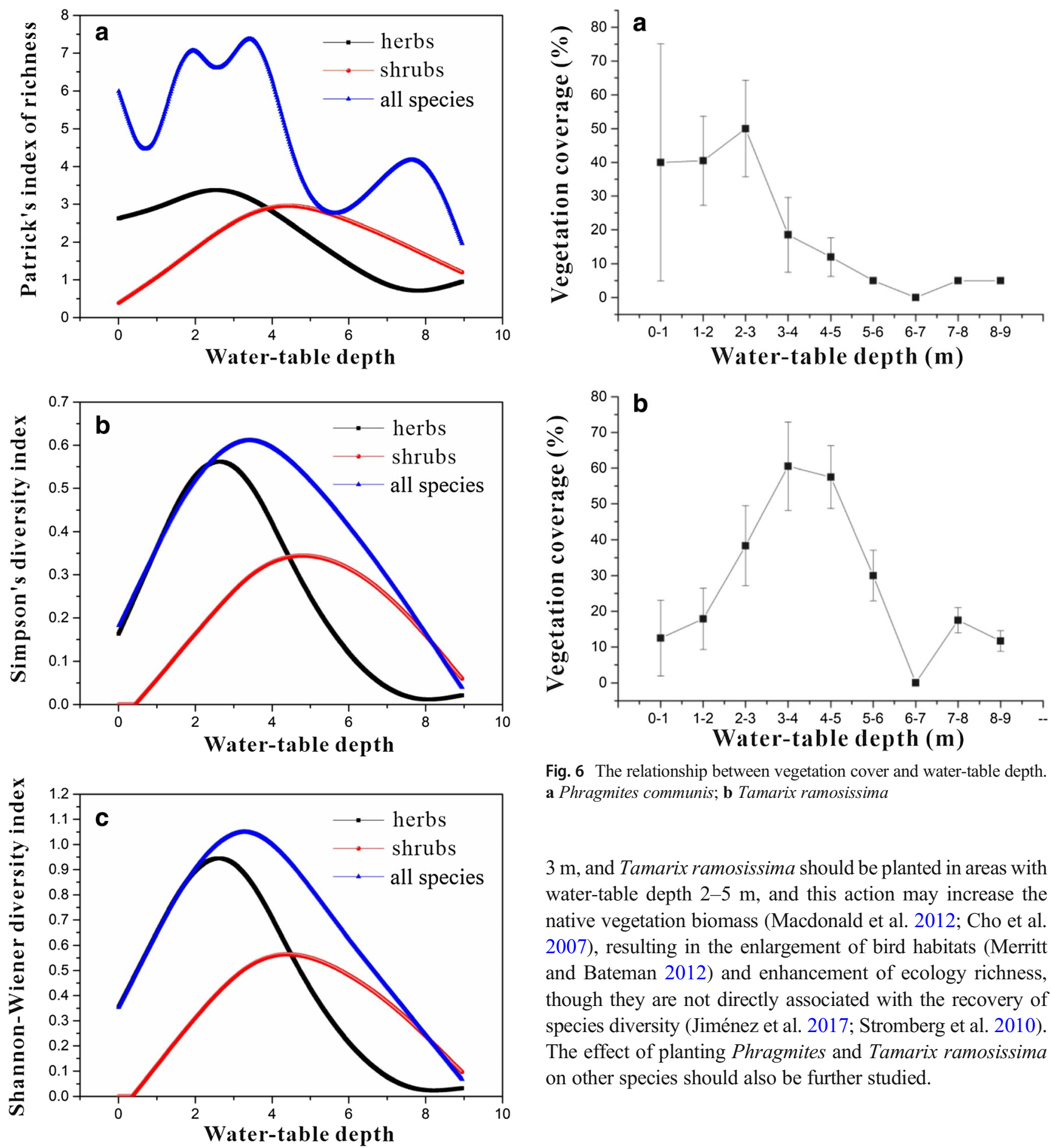

Fig. 6 The relationship between vegetation cover and water-table depth. a Phragmites communis; b Tamarix ramosissima

$3 \mathrm{~m}$, and Tamarix ramosissima should be planted in areas with water-table depth $2-5 \mathrm{~m}$, and this action may increase the native vegetation biomass (Macdonald et al. 2012; Cho et al. 2007), resulting in the enlargement of bird habitats (Merritt and Bateman 2012) and enhancement of ecology richness, though they are not directly associated with the recovery of species diversity (Jiménez et al. 2017; Stromberg et al. 2010). The effect of planting Phragmites and Tamarix ramosissima on other species should also be further studied.

Fig. 5 The response curves of the species diversity indices along the water-table depth gradient: a Patrick's richness index; b Simpson's diversity index; c The Shannon-Wiener diversity index

1997), vegetation planted by humans has been common in many regions (Zhang et al. 2016). Based on the foregoing analysis, Phragmites communis and Tamarix ramosissima may be extensively planted due to their broad distribution as well as their ability to resist droughts. Phragmites communis should be planted in areas with water-table depth of less than

\section{Conclusions}

Because of arid climates and intensive river water allocation to irrigation, plant distribution in the Manasi riparian zone is primarily regulated by groundwater and soil water. Moreover, salt stress conferred effects on species distribution. As the source of soil water is groundwater, the water-table depth determines species composition and diversity in the riparian zone. 
Given the results of the Gaussian model and generalised additive models, the optimal water-table depth in maintaining a high level of species diversity and for meeting the growth needs of major species should be 1-4 m. The critical watertable depth was found to be nearly $6 \mathrm{~m}$. These results might be beneficial in interdisciplinary studies and risk analyses such as the assessment of the effects of groundwater pumping on riparian species.

Phragmites communis and Tamarix ramosissima are two typical species of herb and shrub, respectively, that can grow in conditions that have a variety of water-table depths. In regard to the effective reconstruction of Manasi River riparian vegetation, Phragmites communis should be planted in areas with water-table depths less than $3 \mathrm{~m}$, while Tamarix ramosissima should be planted in areas with water-table depth range $2-5 \mathrm{~m}$.

Funding information This research was supported by the National Natural Science Foundation of China (No. U1603243).

Open Access This article is licensed under a Creative Commons Attribution 4.0 International License, which permits use, sharing, adaptation, distribution and reproduction in any medium or format, as long as you give appropriate credit to the original author(s) and the source, provide a link to the Creative Commons licence, and indicate if changes were made. The images or other third party material in this article are included in the article's Creative Commons licence, unless indicated otherwise in a credit line to the material. If material is not included in the article's Creative Commons licence and your intended use is not permitted by statutory regulation or exceeds the permitted use, you will need to obtain permission directly from the copyright holder. To view a copy of this licence, visit http://creativecommons.org/licenses/by/4.0/.

\section{References}

Boonekauffman J, Beschta R, NickOtting DL (1997) An ecological perspective of riparian and stream restoration in the western United States. Fisheries 22(5):13. https://doi.org/10.1577/15488446(1997)022<0012:AEPORA>2.0.CO;2

Carothers SW, Johnson RR, Aitchison SW (1974) Population structure and social organization of southwestern riparian birds. Integr Comp Biol 14(1):97-108. https://doi.org/10.1093/icb/14.1.97

Chen Y, Zhang X, Zhu X (2004) Analysis on the ecological benefits of the stream water conveyance to the dried-up river of the lower reaches of Tarim River, China. Sci China Series D: Earth Sci 47: 1053-1064

Chen T, De Jeu RA, Liu YY, Der Werf GR, Dolman AJ (2014) Using satellite-based soil moisture to quantify the water driven variability in NDVI: a case study over mainland Australia. Remote Sens Environ 140(140):330-338. https://doi.org/10.1016/j.rse.2013.08. 022

Cho M A, Skidmore A K, Corsi F, van Wieren S E, Sobhan I (2007) Estimation of green grass/herb biomass from airborne hyperspectral imagery using spectral indices and partial least squares regression. Int J Appl Earth Obs Geoinf 9(4):414-424. https://doi.org/10.1016/ j.jag.2007.02.001
Ellis LM (1995) Bird use of saltcedar and cottonwood vegetation in the Middle Rio Grande Valley of New Mexico, USA. J Arid Environ 30(3):339-349. https://doi.org/10.1016/S0140-1963(05)80008-4

Elmore AJ, Manning SJ, Craine MJM (2006) Decline in alkali meadow vegetation cover in California: the effects of groundwater extraction and drought. J Appl Ecol 43(4):770-779. https://doi.org/10.2307/ 3838433

Fan WY, Wang XA, Wang C, Guo H, Zhao XJ (2006) Niches of major plant species in Malan forest standing in the Loess Plateau. Acta Botan Boreali-Occiden Sin 26:157-164 (In Chinese with English abstract)

Gao XM, Huang JH, Wan SQ (1997) Ecological studies on the plant community succession on the abandoned cropland in Taibaishan, Qinling Mountains. I. The community a diversity feature of the successional series. Acta Ecol Sin 17:619-625 (In Chinese with English abstract)

Gorai M, Ennajeh M, Khemira H, Neffati M (2010) Combined effect of $\mathrm{NaCl}$-salinity and hypoxia on growth, photosynthesis, water relations and solute accumulation in Phragmites australis plants. Flora 205(7):462-470. https://doi.org/10.1016/j.flora.2009.12.021

Gregory Wallace JB (1997) Multiple trophic levels of a forest stream linked to terrestrial litter inputs. Science 277(5322):102-104. https://doi.org/10.1126/science.277.5322.102

Gumiero B, Rinaldi M, Belletti B, Lenzi D, Puppi G (2015) Riparian vegetation as indicator of channel adjustments and environmental conditions: the case of the Panaro River (Northern Italy) $[\mathrm{J}]$. Aquat Sci 77:563-582

Hao X, Li W, Huang X, Zhu C, Ma J (2009) Assessment of the groundwater threshold of desert riparian forest vegetation along the middle and lower reaches of the Tarim River, China. Hydrol Process 24(2): 178-186. https://doi.org/10.1002/hyp.7432

Hao X, Li W, Huang X et al (2010) Assessment of the groundwater threshold of desert riparian forest vegetation along the middle and lower reaches of the Tarim River, China[J]. Hydrol Process 24(2): $178-186$

Jackson RB, Canadell J, Ehleringer JR, Mooney HA, Sala OE, Schulze ED (1996) A global analysis of root distributions for terrestrial biomes. Oecologia 108(3):389-411. https://doi.org/10.2307/4221432

Jansson R, Laudon H, Johansson E, Augspurger C (2007) The importance of groundwater discharge for plant species number in riparian zones. Ecology 88:131-139. https://doi.org/10.2307/27651074

Jiménez L, Juliana A, Pérez-Salicrup DR, Figueroa Rangel BL (2017) Are changes in remotely sensed canopy cover associated to changes in vegetation structure, diversity, and composition in recovered tropical shrublands? Plant Ecol 218(8):1021-1033. https://doi.org/10. 1007/s11258-017-0750-x

Jin X, Liu J, Wang S, Xia W (2016) Vegetation dynamics and their response to groundwater and climate variables in Qaidam Basin, China. Int J Remote Sens 37(3):710-728. https://doi.org/10.1080/ 01431161.2015 .1137648

Klijn F, Witte JPM (1999) Eco-hydrology: groundwater flow and site factors in plant ecology. Hydrogeol J 7(1):65-77. https://doi.org/ $10.1007 / \mathrm{s} 100400050180$

Lammerts EJ, Maas C, Grootjans AP (2001) Groundwater variables and vegetation in dune slacks. Ecol Eng 17(1):33-47. https://doi.org/10. 1016/s0925-8574(00)00130-0

Le Maitre DC, DF Scott, C Colvin (1999) Review of information on interactions between vegetation and groundwater. Water S A 25(2). https://doi.org/10.1038/ajg.2015.18

Lite SJ, Bagstad KJ, Stromberg JC (2005) Riparian plant species richness along lateral and longitudinal gradients of water stress and flood disturbance, San Pedro River, Arizona, USA. J Arid Environ 63(4):1-813. https://doi.org/10.1016/j.jaridenv.2005.03.026

Liu H, Long Z, Deng R, Lu M, L1 H, Meng J (2012) Effects of Paspalum notatumn in soil and water conservation and goat fattening on degraded slope-land. Guizhou Agric Sci 40(7):145-148 
Lomeli-Rodriguez, Monica, Rivera-Toledo et al (2017) Process Intensification of the Synthesis of Biomass-Derived Renewable Polyesters: Reactive Distillation and Divided Wall Column Polyesterification[J]. Ind Eng Chem Res 56(11):3017-3032. https://doi.org/10.1021/acs.iecr.6b04806

Loster DS (1988) The Number and Distribution of Vascular Plant Species in Island Forest Communities in the Northern Part of the West Carpathian Foothills[J]. Folia Geobotanica Phytotaxonomica 23(1):1-16

Lv J, Wang X, Zhou Y, Qian K, Wan L, Eamus D, Tao Z (2013) (2013) groundwater-dependent distribution of vegetation in Hailiutu River catchment: a semi-arid region in China. Ecohydrology. 6(1):142149. https://doi.org/10.1002/eco.1254

Lymbery AJ, Doupé RG, Pettit NE (2003) Effects of salinisation on riparian plant communities in experimental catchments on the Collie River, Western Australia. Aust J Bot 51(6):667-672. https:// doi.org/10.1071/BT02119

Macdonald RL, Burke JM, Chen HYH, Prepas EE (2012) Relationship between aboveground biomass and percent cover of ground vegetation in Canadian boreal plain riparian forests. For Sci 58(1):47-53. https://doi.org/10.5849/forsci.10-129

Merritt DM, Bateman HL (2012) Linking stream flow and groundwater to avian habitat in a desert riparian system. Ecol Appl 22(7):19731988. https://doi.org/10.2307/41723108

Rundel PW, Sturmer SB (1998b) Native plant diversity in riparian communities of the Santa Monica Mountains, California. Madroño 45(2):93-100. https://doi.org/10.2307/41425248

Smith SD, Devitt DA, Sala A, Cleverly JR, Busch DE (1998) Water relations of riparian plants from warm desert regions. Wetlands 18(4):687-696. https://doi.org/10.1007/BF03161683

Srivastava DS, Jefferies RL (1995) Mosaics of vegetation and soil salinity: a consequence of goose foraging in an arctic salt marsh. Can J Bot 73(1):75-83. https://doi.org/10.1139/b95-010

Ström ML, Jansson R, Nilsson C (2012) Projected changes in plant species richness and extent of riparian vegetation belts as a result of climate-driven hydrological change along the Vindel River in Sweden. Freshw Biol 57(1):49-60. https://doi.org/10.1111/j.13652427.2011.02694.x

Stromberg JC (2007) Seasonal reversals of upland-riparian diversity gradients in the Sonoran Desert. Divers Distrib 13:70-83. https://doi. org/10.1111/j.1472-4642.2006.00295.x

Stromberg JC (2010) Instream flow models for mixed deciduous riparian vegetation within a semiarid region[J]. River Res Appl 8(3):225235

Stromberg JC, Tiller R, Richter B (1996) Effects of groundwater decline on riparian vegetation of semiarid regions: the San Pedro, Arizona. Ecol Appl 6(1):113. https://doi.org/10.2307/2269558

Ter Braak CJF, Šmilauer P (2002) Canoco for Windows. Version 4.5. Plant Research International, Wageningen, The Netherlands

Ter Braak CJF, Colin Prentice I (1988) A theory of gradient analysis[J]. Adv Ecol Res 18(2004):271-317
Wallace JB, Eggert SL, Meyer JL, Webster JR (1997) Multiple trophic levels of a forest stream linked to terrestrial litter inputs. Science 277(5322):102-104. https://doi.org/10.1126/science.277.5322.102

Wang W, Wang Z, Hou R, Guan L, Dang Y, Zhang Z, Wang Z (2018) Modes, hydrodynamic processes and ecological impacts exerted by river-groundwater transformation in Junggar Basin, China. Hydrogeol J 26(5):1547-1557. https://doi.org/10.1007/s10040$018-1784-4$

Ward T (2001) Biodiversity: towards a unifying theme for river ecology. Freshw Biol 46(6):807-819. https://doi.org/10.1046/j.1365-2427. 2001.00713.x

Wer B, Fu L, Fan F, Zhang C, Jie W, Dong S (2017) Remote sensing monitoring of wetlands dynamics in the Manas River basin from 1998 to 2015 (in Chinese). Remote Sens Land Resour 29(S1):90 94. https://doi.org/10.6046/gtzyyg.2017.s1.15

West RM (2012) Generalised additive models, modern methods for epidemiology. Springer, Dordrecht, The Netherlands

Xiong SJ, Johansson ME, Hughes FMR, Hayes A, Richards KS, Nilsson C (2003) Interactive effects of soil moisture, vegetation canopy, plant litter and seed addition of plant diversity in a wetland community. J Ecol 91(6):976-986. https://doi.org/10.1046/j.1365-2745. 2003.00827.x

Yang G (2017) Water cycle process simulation under the condition of water saving irrigation in Manas River basin. Shihezi University, Shihezi, China

Yang L, Wei W, Chen L, Chen W, Wang J (2013) Response of temporal variation of soil moisture to vegetation restoration in semi-arid loess plateau, China. CATENA 115:123-133. https://doi.org/10.1016/j. catena.2013.12.005

Yang G, He XL, Li XL, Li A, Li Q (2017) Transformation of surface water and groundwater and water balance in the agricultural irrigation area of the Manas River basin, China. Int J Agric Biol Eng 10(4):107-118. https://doi.org/10.25165/j.ijabe.20171004.3461

Zhang J (2004) Quantitative ecology. Science Press, Beijing

Zhang B, He C, Burnham M, Zhang L (2016) Evaluating the coupling effects of climate aridity and vegetation restoration on soil erosion over the Loess Plateau in China. Sci Total Environ 539:436-449. https://doi.org/10.1016/j.scitotenv.2015.08.132

Zhu J, Yu J, Wang P, Yu Q (2011) Interpreting the groundwater attributes influencing the distribution patterns of groundwater-dependent vegetation in northwestern China. Ecohydrology 5(5). https://doi.org/ $10.1002 /$ eco. 249

Zhu ZL, Liu et al (2013) Diversity of plant communities of new rural public green spaces in Yangtze Delta region of China[J]. J Food Agric Environ 11(2):1458-1455

Publisher's note Springer Nature remains neutral with regard to jurisdictional claims in published maps and institutional affiliations. 